\title{
Revascularization/Revitalization \& Regeneration in Endodontics - Quo Vadis?
}

\author{
James L Gutmann* \\ Department of Dentistry, Texas A \& M University, USA
}

*Corresponding author: James L Gutmann, Professor Emeritus, College of Dentistry, Texas A \& M University, Dallas, Texas, USA

Submission: 監 November 16, 2017; Published: 海 November 29, 2017

\section{Opinion}

Endodontics (Endodontology) is that branch of dentistry that deals with the morphology, physiology, and pathology of the human dental pulp and tooth-supporting peri-radicular tissues. Management of diseases of these tissues clinically and technically is often quite challenging due to the highly diverse anatomical nature of the pulpal space, and the ability of root canal procedures to remove the diseased pulp and permit healing of the supporting tissues.

In a small percentage of teeth that require treatment, the formation of the apical root structure (Hertwigs Epithelial Root Sheath - HERS) may be incomplete (open apex) due to trauma or carious invasion of the pulp. In these situations alternative procedures have been identified, with the regeneration of a functional pulp tissue as optimal [1]. While optimal, there are no randomized clinical trials upon which to base treatment decisions [2]. Outcomes have been scanty at best with speculation as to success based on two-dimensional radiographic findings. Furthermore, clinical protocols are highly variable with claims being made by authors as to what is the best choice [3-8]. Moreover, etiological factors, such as what caused the pulpal necrosis and its management may impact on the desired outcomes. In light of these issues, some authors have expressed concerns relative to variables that will impact greatly on the anticipated outcomes, such as repair vs. regeneration, availability of competent cell populations, ability to obtain impacting vasculogenesis/angiogensis along with neurogenesis/re-innervation, the nature of the original defect in the pulp or root, ability to sterilize the entire canal space, tissue responses that include mineralization of the pulpal space and hurdles involved in clinical protocols and applications [1,9-15].

In the case of trauma where the tooth has been avulsed, replantation is recommended within $30 \mathrm{~min}$ to enable the possibility of pulpal revascularization, with retention of pulpal viability. In the case of carious invasion and pulpal death, often with a concomitant peri-radicular lesion, revascularization/revitalization or regenerative procedures are recommended and many case reports or series have been published that describe this technique $[1,6,10,16]$. While the attempt to revascularize the traumatized dental pulp is reasonable and some success has been achieved clinically, the use of the so-called "revascularization/revitalization or regenerative" procedures can be questioned as to their validity, purpose and outcome. Furthermore, while research into these processes has received a great deal of media attention within dentistry He et al. [17], being called "regenerative endodontics" Hargreaves et al. and Diogenes et al. [1,18], there appears to be much speculation and lack of a clear vision as to where these efforts are going and what will ultimately be the future of these procedures in tooth retention. Moreover, the idea of regenerative endodontics lacks some validity from multiple standpoints. First, the scope of the specialty of endodontics consists of at least fifteen specific procedures according to the American Association of Endodontists (AAE), of which regeneration is cited as only one, therefore it would be a misnomer to label it as regenerative endodontics; endodontics is not being regenerated, rather the attempts are to regenerate pulpal tissue or to stimulate potentially capable mesenchymal cells to form tooth related tissues, such as pulpal-like tissues [19]. Second, regeneration in it truest sense, when it comes to pulp tissues requires a re-growth of the dental pulp with all of its characteristics and product formation, the latter being dentin. Once the dental papilla has been destroyed due to excessive trauma or bacterial infection, resurrection of competent cells is speculative at best, although reports indicate that in some cases residual, competent pulp cells may remain [20]. To date this has not been demonstrated and achieved predictably on a clinical basis.

When it comes to revascularization of the empty pulpal space in teeth with open apices and necrotic pulps, the in growth of connective tissue, some vascular and neural elements and an osteocementum matrix has been shown in some cases, along with what appears to be radio-graphically a reduction in the pulpal space; in some case root lengthening may occur that may be due to persistent elements from HERS. However, regeneration of pulp and the production of dentin is highly suspect and unconvincing [20], unless there were remnants of the dental papilla and HERS in the apical region of the open apex, or residually present in the root canal. Have some teeth been retained using these procedures - yes, numerous empirical case reports have appeared in the last 
5 years and the Journal of Endodontics has devoted an entire section monthly to highlight research in this area! Could they have been retained using other more traditional procedures, such as apexification-yes [12]! However, neither procedure has been shown to be superior to the other in tooth retention, although a regenerative procedure may result in increased root thickness and length [12] The choice may reside in the hands of the clinician until irrefutable research including clinical trials can substantiate superiority - the evidence of which may not be at the highest level. However, one of the major claims being made for the use of these procedures is the possibility of strengthening the tooth root with additional hard tissue deposition - but is it dentin or an osteocementum type of tissue and is it intimately locked into the dentin to enable root strengthening? $[4,5,7,20]$ In essence achievements in this regard may be better characterized as a "guided tissue repair" as opposed to revascularization/revitalization or regeneration [18]. This may especially be true when complete bacterial (gram negative species) elimination cannot be achieved and the presence of their lipopolysaccharides may, through bone sialoprotein gene expression, stimulate an osteocementum response into the root canal [21].

Fortunately research in the area of stem cells, scaffolds, growth factors and platelet-rich fibrin for tissue regeneration is going forward to address the issues identified $[1,6,8,9,14,18,19,22,23]$. Yet, still, the concepts of revascularization and regeneration of the dental pulp lack clarity and purpose and the outcomes are highly unpredictable $[7,9,10,13,14,16]$.

If research can validate the procedures proffered for the management of compromised pulps and open-apex teeth, will they be available for all teeth, regardless of the status of root development? Crucial in achieving this will be the ability to completely decontaminate the entire root canal system $[10,11,13]$. Will these validated procedures change the landscape of the specialty of endodontics as we know it today? While the technical aspects of current root canal procedures have received major boosts in instruments and materials, will these be the same for the application of revascularization and regenerative techniques that some investigators envision. Speaking of investigators vision, the question still remains as stated in the title of the article...Quo Vadis?

In some respects this perspective as presented, which barely scratches the surface of the challenges at hand, is heavily overshadowed by social media's emphasis on the two-dimensional radiographic appearance of root canal procedures, with the focus on being the technological management of complex root canal systems. Being left behind is the emphasis on the biological basis of what endodontology is all about and the push to strategically bring to fruition the realization of revascularization/revitalization and regenerative procedures for the retention of all teeth...leaving the question of "Quo Vadis?" unanswered.

\section{References}

1. Hargreaves KM, Diogenes A, Teixeira FB (2013) Treatment options: biological basis of regenerative endodontic procedures. J Endod 39(3 Suppl): S30-S43.
2. Torabinejad M, Nosrat A, Verma P, Udochukwu O (2017) Regenerative endodontic treatment or mineral triocide aggregate apical plug in teeth with necrotic pulps and open apices: a systematic review and metaanalysis. J Endod 43(11): 1806-1820.

3. Namour M, Theys S (2014) Pulp revascularization of immature permanent teeth: a review of the literature and a proposal of a new clinical protocol. Scientific World J 2014: 737503.

4. Wang Y, Zhu X, Zhang C (2015) Pulp revascularization on permanent teeth with open apices in a middle-aged patient. J Endod 41(9): 15711575 .

5. Dudeja PG, Grover S, Srivastava D, Dudeja KK, Sharma V (2015) Pulp revascularization-its your future whether you know it or not? J Clin Diag Res 9(4): ZR01-ZR04.

6. Ray HL, Marcelino J, Braga R, Horwat R, Lisien M (2016) Long-term follow up of revascularization using platelet-rich fibrin. Dent Traumatol 32(1): $80-84$

7. Antunes LS, Salles AG, Gomes CC, Andrade TB, Delmindo MP, et al. (2016) The effectiveness of pulp revascularization in root formation of necrotic immature permanent teeth; a systematic review. Acta Odontol Scand 74(3): 161-169.

8. Strombolsky C, Rodríguez-Benítez S, Gutiérrez Pérez JL, Torres-Lagares D, Martín-González J, et al. (2016) Histologic characterization of regenerated tissues after pulp revascularization of immature dogteeth with apical periodontitis using tri-antibiotic paste and platelet-rich plasma. Arch Oral Biol 71: 122-128.

9. Kim SG, Zhou J, Ye L, Cho S, Suzuki T, et al. (2012) Regenerative endodontics: barriers and strategies for clinical translation. Dent Clin North Am 56(3): 639-649.

10. Wigler R, Kaufman AY, Lin S, Steinbock N, Hazan MH, et al. (2013) Revascularization: a treatment for permanent teeth with necrotic pulp and incomplete root development. J Endod 39(3): 319-326.

11. Lin LM, Ricucci D, Huang GT (2014) Regeneration of the dentine-pulp complex with retivalization/revascularization therapy: challenges and hopes. Int Endod J 47(8): 713-724.

12. Lin J, Zeng Q Wei X, Cui M, Gu J, et al. (2017) Regenerative endodontics versus apexificaton in immature permanent teeth with apical periodontitis: a prospective randomized controlled study. J Endod 43(11): 1821-1827.

13. Albuquerque MTP, Valera MC, Nakashima M, Nör JE, Bottino MC (2014) Tissue-engineering-based strategies for regenerative endodontics. J Dent Res 93(12): 1222-1231.

14. Huang GT, Garcia-Godoy F (2014) Missing concepts in de novo pulp regeneration. J Dent Res 93: 717-724.

15. Song M, Cao Y, Shin SJ, Shon WJ, Chugal N, et al. (2017) Revascularizationassociated intracanal calcification: assessment of prevalence and contributing factors. J Endod S0099-2399(17): 30771-30779.

16. Lee BN, Moon JW, Chang NS, Hwang IN, Oh WM, et al. (2015) A review of the regenerative endodontic procedure. Rest Dent Endod 40(3): 179187.

17. He L, Kim SG, Gong Q Zhong J, Wang S, et al. (2017) Regenerativ endodontics for adult patients. J Endod 43(9S): S57-S64.

18. Diogenes A, Ruparel NB, Shiloah Y, Hargreaves KM (2016) Regenerative endodontics: a way forward. J Am Dent Assoc 147(5): 372-380.

19. Cao Y, Song M, Kim E, Shon W, Chugal N, et al. (2015) Pulp-dentin regeneration: current state and future prospects. J Dent Res 94(11): 1544-1551.

20. Saoud TM, Zaazou A, Nabile A, Mousas S, Aly HM, et al. (2015) Histological observations of pulpal replacement tissue in immature dog teeth after revascularization of infected pulps. Dent Traumatol 31(3): 243-249. 
21. Lertchirakarn V, Aguilar P (2017) Effects of lipopolysaccharide on the proliferation and osteogenic differention of stem cells from the apical papilla. J Endod 43(11): 1835-1840.

22. Piva E, Silva AF, Nör JE (2014) Functionalized scaffolds to control dental pulp stem cell fate. J Endod 40(4 Suppl): S33-S40.
23. Pinto N, Harnish A, Cabrera C, Andrade C, Druttman T, et al. (2017) An innovative regenerative endodontic procedure using leukocyte and platelet-rich fibrin associated with apical surgery: a case report. J Endod 43(11): 1828-1834. 